\title{
Uma "máquina" de matar: a guerra secreta da CIA
}

\section{Raquel Anne Lima de Assis ${ }^{I}$}

Resenha recebida em 23/11/2016 e aprovada em 15/12/2016.

Os atentados terroristas do 11 de setembro de 2001 marcariam o fim do Tratado de Vestefália? Trata-se de um acordo de paz na Europa no século XVII, ao final da guerra dos Trintas Anos, que levou o surgimento das nações modernas, suas identidades nacionais e a formação de exércitos permanentes. Pois, até então as guerras eram realizadas através de mercenários. Segundo Dewey Clarridge, ex-agente da CIA (Agência Central de Inteligência) e fundador do Centro Contraterrorista da agência, sim, seria o fim do tratado ${ }^{\text {II }}$. Isso porque após o ataque as Torres Gêmeas do World Trade Center realizado pela Al-Qaeda, grupo terrorista liderado por Osama bin Laden, a forma de combater dos EUA se transformou em uma guerra secreta, uma guerra nas sombras.

Sendo assim, Mark Mazzetti na obra Guerra Secreta: A CIA, um exército invisível e o combate nas sombrastem como objetivo apresentar como foi realizado esse tipo de guerra empreendido pela CIA e pelo Pentágono. Mazzetti nasceu em 13 de maio de 1974, Washington, D.C., EUA, e teve sua formação na Duke University e naOxford University. É correspondente de segurança nacional do New York Times e em 2009 foi vencedor do Prêmio Pulitzer por seu trabalho em revelar a reação de Washington à forte violência no Paquistão e no Afeganistão. Também venceu outros prêmios como o George PolkAward e o LivingtonAward, por desvendar o caso da destruição de fitas de interrogatório da CIA. Tambémpublicou no Los Angeles Times, U.S. News\& World Report e The Economist. Outro livro de suaautoria é o The Way of the Knife: The CIA, a Secret Army, and a War at the Ends of the Earth (2013).

O autor começa apresentando como a imagem e credibilidade da CIA antes do 11 do setembro tanto para o povo americano como para o próprio governo estava deteriorada. Isso devido às diferentes crises e falhas cometidas pela agência anos anteriores, como caso dos Irã-Contra (1986), durante o governo de Ronald Reagan. Em tal escândalo figuras-chaves da CIA estavam envolvidas no tráfico de armas para o Irã. Contudo, diante do ataque terrorista de Osama bin Laden esse cenário se transformou. A Agência Central de Inteligência passou a exercer um papel de destaque na guerra contra Al-Qaeda e tinha como objetivo localizar e eliminar seu líder. A agência se transformou na principal arma do governo americano nesta caçada, gerando, assim, aumento em seu orçamento e ganhando maior confiabilidade.

Mas, as mudanças não pararam por aí. A própria função da CIA se transformou. Cada vez mais ela deixou de ser uma agência de espionagem e se tornou uma instituição de operações secretas com o propósito de assassinar. Integrantes das organizações terroristas entravam na lista negra e eram marcados para morrer. Para isto enviavam para o Oriente Médio e norte da África espiões disfarçados e mais preparados para o combate do que para a coleta de informações e análise de inteligência. Outra forma também bastante utilizada, recebendo alto investimento, foram os drones. De uma base nos EUA pilotos controlavam remotamente e através de satélites esses dispositivos capazes de lançar mísseis e destruir completamente seus alvos. Assim, seu pessoal 


\section{RAQUEL ANNE LIMA DE ASSIS}

matava com a garantia que voltaria para casa ao final do dia por não correr risco de um confronto.

Para empreender essas atividades a instituição e o governo americano procuraram, com ajuda de advogados, brechas nas leis. Devido à uma ordem executiva do presidente Gerald Ford a CIA estava proibida de assassinar chefes de Estados e políticos estrangeiros. Era uma tentativa de impor limites aos seus sucessores em atividades obscuras que manchou a agência e os EUA anos anteriores diante de ações semelhantes. Com os atentados do 11 de setembro tal ordem já não tinha tanto valor. Desta forma, matar os inimigos estrangeiros em países que não estavam em guerra contra os estadunidenses ganhou um aparato legal. Contudo, nem sempre a CIA agia conforme os trâmites jurídicos. Como no caso de interrogatórios realizados por meio de torturas em prisões secretas ou ainda quando seus espiões e drones agiam em outros países sem a permissão dos chefes de Estados destes locais.

Entretanto, focando cada vez mais neste tipo de ação, a CIA agiu menos naquilo que ela nasceu para fazer, espionagem. Seu sistema de informação era ineficiente, por isso, dependia de agências de espionagem de outros países. Percebendo essa situação, o Pentágono não ficou satisfeito, pois, careciam de informações para que suas tropas agissem. Desta forma, as próprias Forças Armadas procuraram produzir sua inteligência. $O$ que também contribuiu para a troca de funções entre a CIA e o Pentágono é que este era mais limitado para agir em operações secretas de combate e assassinato em países que não estavam em guerra, pois, geraria crises diplomáticas. Enquanto a CIA possuía acesso mais livre em ações clandestinas com espiões e drones espalhados em diferentes países do Oriente Médio e África e agindo como uma nova "Força Armada" em uma guerra secreta. Ou seja, o Pentágono tinha certo limite para agir nas sombras, o que não impediu sua ação na morte de Osama bin Laden, entretanto, sob a liderança da CIA. Essas inversões de papéis gerou tensões entre ambas instituições pela disputa de território e concessões. Em alguns casos dividiam áreas de operações, mas em outros ambos operavam no mesmo país e de forma independente.

A transposição de tarefas da CIA ocorreu também por meio da terceirização. Empresas eram contratadas para exercer atividades que a agência deveria cumprir, como a própria produção de inteligência, por exemplo. Isso fez com que um empreendimento comercial girasse em torno do órgão em uma busca por lucros nas caçadas e assassinatos de terroristas. Essa privatização fez com que a indústria da inteligência e da defesa que estavam espalhadas por diferentes estados se concentrassem em Washington, D.C., isto é, o mais perto da sua "mina de ouro", a CIA, o Pentágono e a Agência de Segurança Nacional (NSA).

Portanto, Mark Mazzetti nos mostra como em uma década, durante o governo de George W. Bush e Barack Obama,a CIA agiu na caçada contra Osama bin Laden e demais líderes da Al-Qaeda. São apresentadas as operações que estiveram envolvidas e a forma como o faziam que trata-se de uma guerra secreta com o objetivo de matar. Esse tipo de combate é uma tentativa de atuar de uma forma mais "cirúrgica" possível, para que fosse mais precisa e sem tanto "estrondo", mas, não significa que na prática era tão "silenciosa" assim. É a troca do uso de tanques por um exército "invisível”.

Para este trabalho o autor consegue discorrer de uma forma clara e objetiva, se tornando uma leitura fácil. Sendo assim, a obra pode ser utilizada tanto por alunos, 


\section{RAQUEL ANNE LIMA DE ASSIS}

professores, pesquisadores e leigos que estejam interessados em história militar, espionagem e terrorismo. A atualidade do tema contribui para a ampliação do público, pois, são tratados temas que nós presenciamos nos noticiários da TV e da internet. Além de ser bem documentado, indicando suas fontes que são jornais, documentos oficiais e entrevistas. Todavia, o livro carece de mais informações sobre os resultados dos ataques da CIA entre a população civil. Brevemente o autor cita erros que a agência cometeu em suas operações causando a morte destas pessoas, porém, de forma sucinta. Isso pode gerar a ideia que as ações da CIA quase sempre foram um sucesso e que apenas os terroristas que foram mortos. Ao passo que sabemos que muitos civis também foram vítimas.

\section{Notas}

I Mestranda em História Comparada pela UFRJ. Integrante do Grupo de Estudo do Tempo Presente (GET/UFS/CNPq). Bolsista CAPES. Email: raquel@getempo.org. Orientador: Dr. Dilton Cândido S. Maynard (PPGHC/UFRJ-UFS/DHI). Trabalho apoiado pelo projeto "Quando a Guerra chegou ao Brasil: Ataques submarinos e memórias nos mares de Sergipe e Bahia (1942-1945)”, Edital Universal CNPq 2014.

II MAZZETTI, Mark. Guerra Secreta: A CIA, um exército invisível e o combate nas sombras. Trad.: Flávio Gordon. Rio de Janeiro: Record, 2016.

\section{Referência bibliográfica}

MAZZETTI, Mark. Guerra Secreta: A CIA, um exército invisível e o combate nas sombras. Trad.: Flávio Gordon. Rio de Janeiro: Record, 2016. 